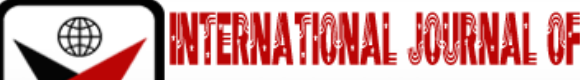

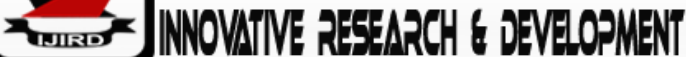

ISSN 2278-0211 (Online)

\section{Value Stream Mapping: A Tool for Waste Reduction}

\author{
Ovundah King Wofuru-Nyenke \\ Lecturer, Department of Mechanical Engineering, \\ Rivers State University, Port Harcourt, Rivers State, Nigeria
}

\begin{abstract}
:
This paper showcases the use of the lean manufacturing tool known as Value Stream Mapping (VSM) as a means of identifying and reducing waste in a water bottling factory. Value Stream Mapping (VSM) is a Lean Manufacturing technique for identifying where wastes occur in a manufacturing process. A Current State Value Stream Map (CVSM) was utilized in identifying the sources of waste in the current state of operations of the water bottling plant. On the other hand, a Future State Value Stream Map (FVSM) was used in proposing an improved state of the plant's production processes. The CVSM aided in discovering that manual inspection was one of the sources of waste in the factory which led to waste in the form of over processing. The FVSM displayed a proposed state with an improvement of manufacturing lead time and cycle time of about 42.1 per cent and 22.2 per cent respectively. The proposed state of the water bottling process also required lesser workers, with a reduction of 2 quality inspectors, therefore a drop in the cost of labour was also achieved.
\end{abstract}

Keywords: Lean manufacturing, value stream mapping, waste reduction, water bottling

\section{Introduction}

Most manufacturing organizations around the world constantly search for innovative methods and techniques to improve their production processes, reduce the wastes generated during production, and consequently, decrease production costs. In manufacturing, the value stream refers to the sequence of events that the manufacturer undergoes to add value to a customer from the initial request by the customer, through to the customer's realization of value. Waste can be described as any aspect of the manufacturing process that does not add value to the product being manufactured, from the customer's perspective. Wastes can be in the form of transportation inefficiencies within the plant, excess unprocessed inventory at the individual stages of production, wasted time and effort related to unnecessary movements by people, unnecessary waiting during production, making more product than is demanded by the customer, carrying out more work than is required and failure of manufactured products to meet customer expectations. The application of lean methods, principles, and tools to the development and manufacture of physical items is referred to as Lean Manufacturing. Moreover, Lean Manufacturing is a method of reducing waste in a production system while maintaining productivity. Value Stream Mapping is a Lean Manufacturing technique for identifying where wastes occur in a manufacturing process, thereby enabling the process improvement personnel to efficiently identify and truncate the various sources of waste encountered during production.

\section{Literature Review}

In the manufacturing sector, several successful implementations of Value Stream Mapping to improve process efficiency have been reported. Wofuru-Nyenkeet al. (2019) have successfully combined the Value Stream Mapping Lean Manufacturing tool with Six Sigma process improvement methodology, to enhance the production process of a water bottling plant. Sasikumar and Kumar (2013) have rightly described Value Stream Mapping as the starting point of any Lean transformation and implementation. In a research study at a company which manufactures Moulded Case Circuit Breakers (MCCB), Sasikumar and Kumar (2013) applied the Value Stream Map (VSM) tool to detect and reduce non-valueadded tasks and suggest a future state to reduce manufacturing lead time and increase value-added time. After representing the current state of production processes at the company on a Current Value Stream Map (CVSM), it was noticed that the total time required to manufacture a product was about 21 days and there was large inventory between processes even when utilization rates of certain processes were less than 96 per cent. As a remedy to these problems, processes were grouped into continuous flow cells, and a pull system was developed by the introduction of supermarkets at the point of raw materials receipt and between the cells. The Future State Map was created and the improved process required 1 less operator, and the total lead time and total processing time dropped to approximately 8 days and 28 minutes respectively. In a similar study, Sabooet al. (2014) achieved even more tremendous gains in their application of Lean Manufacturing Value Stream Mapping technique to reduce the production lead time, inventory, changeover time and improve process operations to meet customer demand. They reduced the production lead time by approximately 71 per 
cent, Work-In-Progress (WIP) inventory was reduced by about 73 per cent, and raw material inventory reduced by about 86 per cent.

Zahraeeet al. (2014) explained that companies use Lean Manufacturing to maintain their competitiveness by increasing the productivity of their manufacturing systems and quality enhancement of the product. They stated that the main contribution of Lean Manufacturing is the identification and elimination of waste. Zahraeeet al. (2014) applied Value Stream Mapping in improving the production line of a company that produces several components for a vehicle assembly line, in order to decrease the waste and non-value-added activities. The goal of the study was to develop a Value Stream Map (VSM) for the production line of a company that produces several components for a vehicle assembly line. The main objectives were to determine and reduce waste for any process which does not add value to the final product in the production line, as well as to decrease production lead time and value-added time.

First, the Current Value Stream Map (CVSM) of the production line was developed using personal interviews, observations and secondary data of the company. It was shown from the Current State Map (CSM) of the production line that led time and value-added time for the product is 23.5 days and 188 seconds respectively. It was observed that the production process was beset by non-value-added activities such as waiting for product, moving raw material from one section to another and large set up times. Subsequently, the Future Value Stream Map (FVSM) was proposed based on the Lean Manufacturing principles to improve total production lead time and value-added time. After implementing the proposed solutions, the process lead time and value-added time reduced to 4.5 days and 166 seconds, respectively, which is an improvement of about 81 per cent and 12 per cent in the production lead time and value-added time, respectively. The study showed that VSM is a useful and applicable approach that can help managers conceptualize the different kinds of wastes and defects in production systems.

Klimecka-Tartar (2017) described Value Stream Mapping as a simple but effective method used for the illustration and redesign of a process flow. In a process improvement exercise carried out by Klimecka-Tartar (2017) the Value Stream Map (VSM) was utilized in a package manufacturing company to increase process efficiency. A Current State Map (CSM) of processes at the Company was developed which aided in effectively identifying the bottlenecks and sources of waste, thereby highlighting the opportunities for improving the production process. After introducing the improvements to the production process, there was a decrease in the manufacturing lead time by about 38 per cent, a decrease of about 9 per cent in the estimated time required to carry out value-added operations, as well as a rise in process efficiency by about 23 per cent.

Chaple and Narkhede (2017) utilized VSM in a discrete manufacturing organization with low volume and high variety products, when they discovered that products which collectively contributed about 70 per cent by quantity to volume of output, were responsible for the largest part of non-value-added costs. The problems with the production process as identified by the Current State Map developed, were less flexibility of the overall system, high inventory, poor 5S and visual management, high material movement, no synchronization in flow, no First-In-First-Out (FIFO) inventory system, batch production at certain places, difficulty to know priority and high downtime at certain workstations. The main practices that were integrated into the production process to eliminate these issues were introduction of a pull system, introduction of supermarket, introduction of safety stocks and an overall process improvement to optimize work hours of labour and production rate of machines. As a consequence of the improvement exercise, the organization reduced lead time by 59 per cent, improved value-added to non-value-added (VA/NVA) ratio by 138 per cent, and reduced inventory by 61 per cent.

In a study by Goriwondoet al. (2011), the VSM tool was used to reduce waste in bread manufacturing. The research critically analysed the company's manufacturing processes to identify the streams of waste. However, in order to maximize the returns from the improvement exercise, the study was focused on a production line that contributes 90 per cent of the company's sales. A current state map was created and data of sources of waste were used to develop a waste ranking algorithm. The company experienced the full spectrum of waste as identified by Liker (2004), although in varying proportions. The waste ranking bar chart showed that the wastes that needed to be minimized in the company are defects, inventory, motion, waiting, overproduction, transportation and inappropriate processing, which had final indication factors of $25.1,19.7,15.1,13.7,11.4,10.6$ and 4.4 per cents respectively. Though the waste ranking bar chart was sufficient for presenting the various forms of waste encountered in the company, a Pareto chart would have been more efficient at ranking the various forms of waste. The future state map was developed where waste due to defects was reduced by 20 per cent by eliminating bottlenecks, unnecessary inventory was reduced by 18 per cent by utilizing FIFO inventory system and waste due to motion was reduced by 37 per cent by transferring only an economic batch quantity between processes. Therefore, on average a 25 per cent waste reduction was achieved in the important areas of unnecessary inventory, defects and motion.

The efficacy of the VSM tool in identifying inefficiencies in material and information flow in a process was further emphasized by the process improvement exercise conducted by Singh et al. (2015) in a Fastener manufacturing company. After investigating the current state Value Stream Map, they proposed that production Kanban, standard work and 5S system should be introduced into the production process to eliminate waste encountered in the form of unused employee potential, overproduction, transportation and material handling. After the improvements were introduced, the future state Value Stream Map showed that the improved process required 2 less operators, lead time was cut by approximately 45 per cent, cycle time decreased by about 9 per cent, there was a large decline in inventory between processes by almost 88 per cent and transportation distance reduced by about 24 per cent.

Similarly, Carvalhoet al. (2019) also combined value stream mapping with Kanban as the Lean Manufacturing tools for identifying and eliminating production flow waste during a cost reduction exercise carried out in an Indian textile company. The company had 22 employees, produced 30 tons per month of textile and stamped on average 4000 sport 
shirts monthly. In the report by Carvalhoet al. (2019), some outdated systems of cost accounting like activity-based costing (ABC) and total absorption costing were reviewed and it was pointed out that even though these traditional cost accounting systems were inadequate, small companies still prefer those traditional cost accounting systems over new and enhanced methods such as the Lean or throughput system. During the study, information such as cycle time, inventory time and the number of employees in each position was obtained from production reports, employees and top managers in order to create the Current Value Stream Map (CVSM). The analysis of the CVSM showed that some of the employees worked in more than one process leading to frequent stops in a process. Also, a high number of stops occurred due to maintenance, and a relatively high machine setup time was observed. Therefore, the forms of waste in the textile company were waste due to inventory and waste due to waiting. By comparing the Lead Time (LT) and Value-Added Time (VAT) the production cycle efficiency for the current state was determined to be 27.67 per cent. The implementation of Kanban was chosen as the Lean Manufacturing tool to solve the inventory problem. This is because the introduction of Kanban cards in the T-shirts store would help in managing the master production schedule and as a consequence, the work in process level would decrease. Consequently, the Future Value Stream Map (FVSM) was developed and a reduction of 3 days in inventory between processes was achieved. As a result, there was a rise in the cycle efficiency to 40.1 per cent. Again, a comparison of value of total inventory between the month of implementing Kanban and the previous month showed a decrease in inventory worth $\mathrm{R} \$ 231,615.34$.

Yuvamitraet al. (2017) explained that Value Stream Mapping is used in visualizing the current production processes for easier understanding and problem identification. They applied the Value Stream Map tool in a rope manufacturing process to decrease the overall time required for the company to deliver the customer's order. The current state Value Stream Map was created and the possible improvements were suggested. The raw material was moved from the current location in the corner of the warehouse to a location closer to the machines. Again, the twisting cell was moved closer to the warehouse and stranding cell, making it easier for the stranding operator to take twisted yarn directly from the basket in the twisting area. Also, the oven was moved to a location closer to the braiding and splicing cells for better process flow. The implemented results were shown in the form of a future state map. For the information flow, the processing time and waiting time were reduced by an estimated 68 per cent and 88 per cent, respectively. For the production processes, the material handling time was reduced by 33 per cent due to the revision of the plant layout. The total cycle time from receiving customer order to shipping was reduced from 36 days to 9 days. This is a reduction of 75 per cent total time from the moment the customer places an order to the time it is shipped.

Zakuan and Saman (2009) applied Lean Manufacturing tools and techniques in a car seat manufacturing process to improve the production system at the manufacturing facility which was operating on a mass production principle. Based on initial observations, the Current Value Stream Map showed that there were several waste areas that can be improved, such as waiting, overproduction, rework, motion, processing, inventory and transportation. The Future State Map constructed in the study showed a significant reduction in lead time, cycle time, changeover time and inventory, when compared to the Current State Map. The main assembly line showed a 70.9 per cent reduction in total lead time, a 21.8 per cent reduction in value added time and for the electronic subassembly line, a 33.7 per cent reduction in total lead time and a 51.3 per cent reduction in value added time.

\section{Materials and Methods}

For reducing waste at the water bottling plant during the process improvement exercise, various machines and tools were encountered and applied. This section lists the various machines and tools that were utilized, within the water bottling plant.

\subsection{Materials}

The machines and tools encountered while collecting data at the water bottling plant are Preform hopper, Krones Contiform Bloc, Krones Modulfill, Krones Contiroll, Krones Variopac Pro, PRS Stretch Wrapper, check sheets for recording defects, measuring cylinder for measuring water volumes and a digital stop watch for measuring cycle time and lead time. 


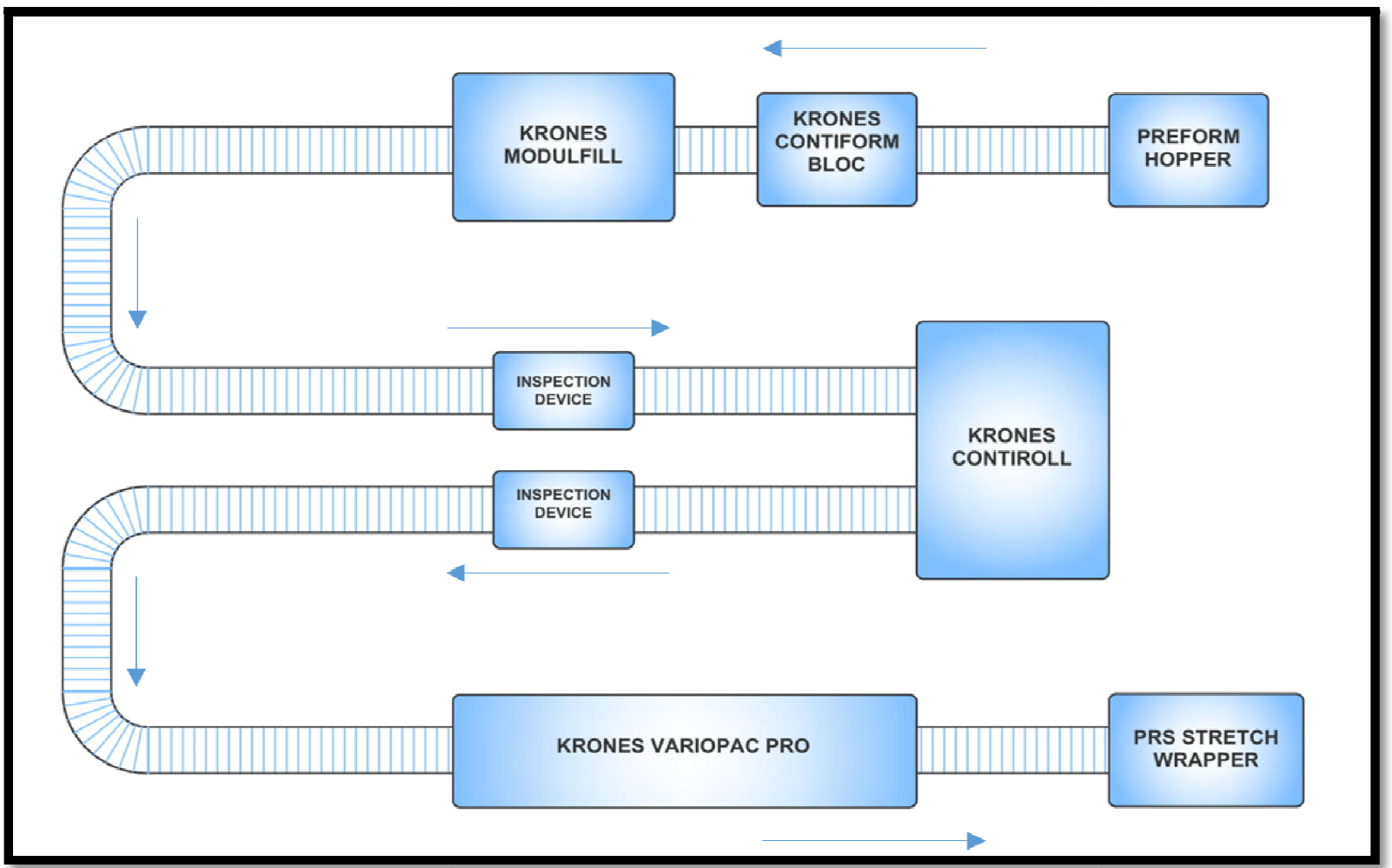

Figure 1: Schematic Diagram of the Bottling Plant Line Layout

\subsection{Methods}

The primary technique used for identifying the sources of waste in the plant is the Value Stream Mapping (VSM) technique. To produce a representative operational state, the VSM was utilized in illustrating all primary work flows, information flow, material flow in process, and critical process measurements. Figure 2 shows the common symbols contained in Value Stream Maps and their meanings.

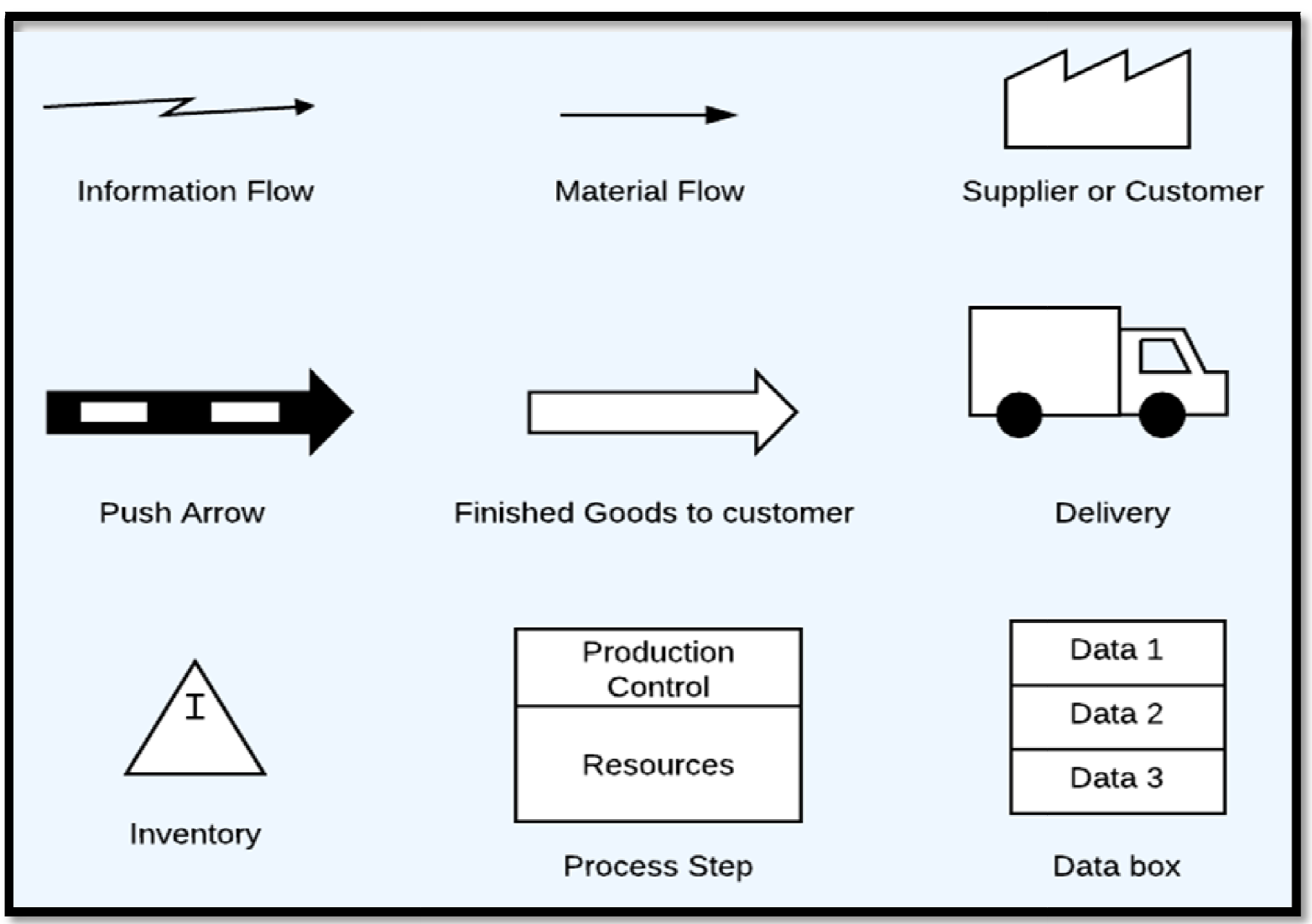

Figure 2: Value Stream Map Symbols (Wofuru-Nyenke et al., 2019) 


\section{Results and Discussion}

This section discusses the results of the Lean Manufacturing process improvement exercise carried out at the water bottling plant, which was producing bottled water of $50 \mathrm{cl}$ volume.

\subsection{Current Value Stream Map of the Water Bottling Process}

In order to highlight the opportunities for improvement, a detailed representation of the processes in the water bottling plant was created on a Current Value Stream Map (CVSM) to show the current state of operations at the bottling plant, which was producing bottled water of $50 \mathrm{cl}$ volume. The data for the current state of the manufacturing process is presented in Table 1 .

\begin{tabular}{|c|c|c|c|c|}
\hline S/No. & Process & Workers & Yield (\%) & Cycle Time (Minutes) \\
\hline 1 & Preform tipping & 1 & 87 & 3 \\
\hline 2 & Bottle blowing & 1 & 90 & 1 \\
\hline 3 & Filling and capping & 2 & 45 & 1 \\
\hline 4 & Inspect water level & 1 & 50 & 2 \\
\hline 5 & Labelling & 1 & 95 & 1 \\
\hline 6 & Inspect labels & 1 & 50 & 2 \\
\hline 7 & Shrink wrapping & 2 & 55 & 2 \\
\hline 8 & Palletizing & 4 & 100 & 3 \\
\hline 9 & Stretch wrapping & 1 & 100 & 3 \\
\hline
\end{tabular}

Table 1: Data for the Current State of the Manufacturing Process

The Current State Value Stream Map is shown in Figure 3. The map depicts the flow of information, which starts with a single client on the right side of the map, then moves on to information exchange within the plant, and finally to the six (6) raw material suppliers (on the left). The first step in the water bottling process is the Preform Tipping operation, where an estimated 17,000 preforms are loaded, into the Preform hopper, in approximately 3 minutes. Figure 3 shows that one (1) operator handles the Preform Tipping operation. Moreover, the operation possesses a yield of 87 per cent. The preforms are then loaded onto a conveyor and delivered to a KronesContiform Bloc blow moulder, where they are blown to create the water bottles. The preforms are transported via a modular linear oven in the first step of the bottle forming process, where infrared radiation is used to heat the preforms to an optimal temperature for processing. Next, the preforms are transferred to the blowing wheel, where they are put into moulds and pressurized air is used to shape them into bottles, in 12 blowing stations. From Figure 3, the operation is overseen by a single operator, and it produces a 90 per cent yield.

The bottles are then transported to a KronesModulfill filler, where water is fed into the bottles until they are filled to the specified level. The bottles are then capped and conveyed to the next phase in the process, where they will be inspected. Two (2) operators monitored the filling and capping operation, which yielded a 45 percent yield, while one inspector was required for the inspection stage. Next, the filled and capped bottles are transported to a KronesContiroll machine where the product labels are glued over the products. The labelling process achieved a 95 per cent yield, with one operator monitoring the operation and an inspector inspecting the labelled goods. Thereafter, the products were fed onto a KronesVariopac Pro shrink-wrapper, where the bottles were grouped into twelves and shrink-wrapped. Two operators monitored the shrink-wrapping operation, which had a 55 percent yield. Finally, bottles were packed and prepared for shipment to clients. First, the products were transported to be palletized and finally, a PRS Stretch Wrapper machine was used in stretch wrapping them. The palletizing and stretch wrapping operations each had one operator, with yields of 100 per cent. Therefore, processes with low yields needed to be optimized. 


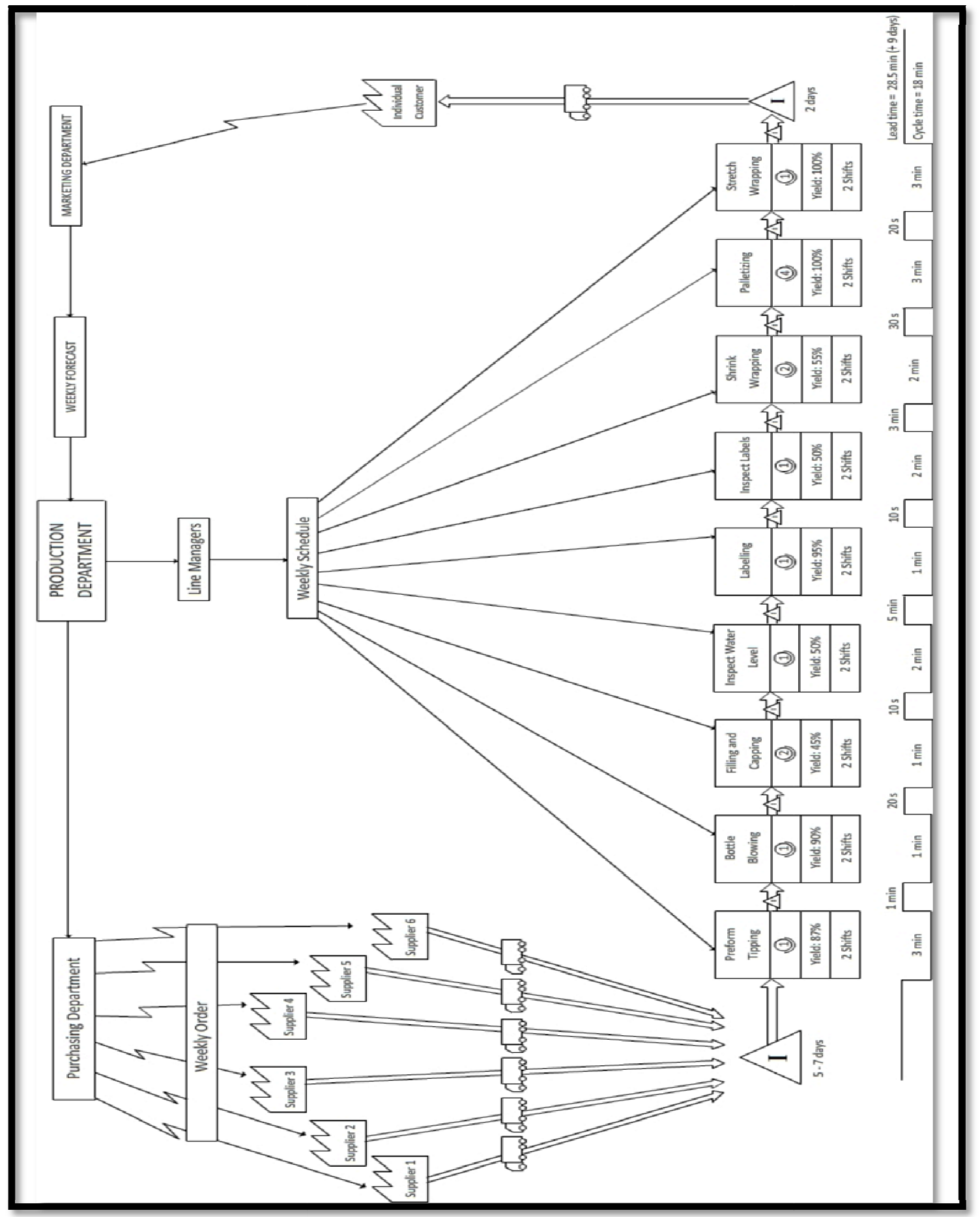

Figure 3: Current Value Stream Map of Production Processes at the Water Bottling Plant

\subsection{Future Value Stream Map of the Water Bottling Process}

The Current Value Stream Map (CVSM) in Figure 3 aided in identifying the major forms of waste in the bottling plant as waste due to defects and waste due to delays. Therefore, the Future Value Stream Map was used to proffer an improved state of the water bottling plant as shown in Figure 4. In Figure 4, the method of inspecting the volume of water in the water bottles, as well as the quality of the labelling task, has been changed to the use of inspection sensor devices. These devices can check the water levels and labels, and instantaneously eliminate defective products from the production line faster than a human. Therefore, the water bottling plant was experiencing waste in the form of overprocessing.

The inspection equipment was already installed at the bottling facility, but they were turned off due to a fluctuating water volume problem, and human inspectors were hired to inspect the products instead. Therefore, it was discovered that fixing the main cause of the water variation problem and deploying the inspection equipment will eliminate the requirement for two (2) inspectors and the cost of paying them. Furthermore, if the future state map is applied, lead time will be decreased by 42.1 percent, while cycle time will be decreased by about 22.2 percent. Table 2 shows the data for the future state of operations of the water bottling plant. From the data in Table 2 and the Future Value Stream Map in Figure 4, the number of production processes required to produce the 50cl bottled water within the bottling plant has been reduced from 9 processes to 7 processes. 


\begin{tabular}{|c|c|c|c|c|}
\hline S/No. & Process & Workers & Yield (\%) & Cycle Time (minutes) \\
\hline 1 & Preform tipping & 1 & 87 & 3 \\
\hline 2 & Bottle blowing & 1 & 90 & 1 \\
\hline 3 & Filling and capping & 2 & 45 & 1 \\
\hline 4 & Labelling & 1 & 95 & 2 \\
\hline 5 & Shrink wrapping & 2 & 55 & 3 \\
\hline 6 & Palletizing & 4 & 100 & 3 \\
\hline 7 & Stretch wrapping & 1 & 100 & \\
\hline
\end{tabular}

Table 2: Data for the Future State of the Manufacturing Process

\section{Conclusion}

This research has showcased the use of the Lean Manufacturing tool known as the Value Stream Map in identifying sources of waste and proffering improvement solutions. The major sources of waste and their areas of occurrence within the water bottling process were identified using the Current Value Stream Map. On the other hand, the Future Value Stream Map was used to propose and highlight the improvements to the production process, which include reduction of two (2) quality inspectors and a decrease in manufacturing lead time and cycle time by 42.1 per cent and 22.2 per cent, respectively. Therefore, if the proposed state of operations of the water bottling plant is implemented the plant will be able to achieve a reduction in labour costs.

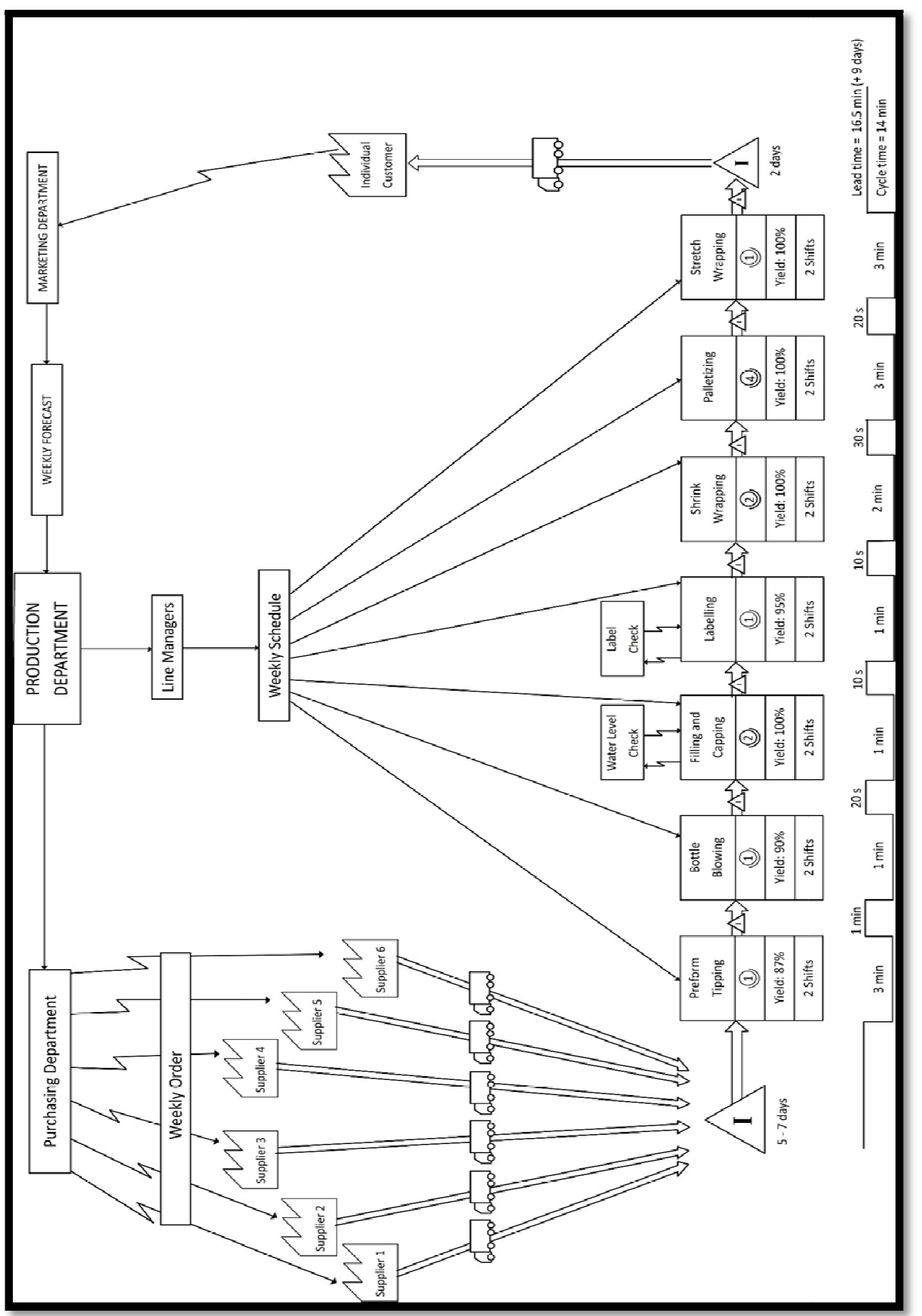

Figure 4: Future Value Stream Map of Production Processes at the Water Bottling Plant 


\section{References}

i. Carvalho, C.P., Gonçalves, L.W.N. \& Silva, M.B. (2019). Value Stream Mapping as a Lean Manufacturing Tool: A New Account Approach for Cost Saving in a Textile Company. International Journal of Production Management and Engineering, 7(1), 1 - 12.

ii. Chaple, A.P. \&Narkhede, B.E. (2017). Value Stream Mapping in a Discrete Manufacturing: A Case Study. International Journal of Supply Chain Management, 6(1), 55 - 67.

iii. Goriwondo, W.M., Mhlanga, S. \&Marecha, A. (2011). Use of the Value Stream Mapping Tool for Waste Reduction in Manufacturing. Case Study for Bread Manufacturing in Zimbabwe. Proceedings of the 2011 International Conference on Industrial Engineering and Operations Management, at Kuala Lumpur, Malaysia.

iv. Klimecka-Tatar, D. (2017). Value Stream Mapping as Lean Production Tool to Improve the Production Process Organization - Case Study in Packaging Manufacturing. Production Engineering Archives, 17, 41 - 45.

v. Liker, J.K. (2004). The Toyota Way: 14 Management Principles from the World's Greatest Manufacturer. New York: McGraw-Hill.

vi. Saboo, A., Garza-Reyes, J.A., Er A. \& Kumar, V. (2014). A VSM Improvement-based Approach for Lean Operations in an Indian Manufacturing SME. International Journal of Lean Enterprise Research, 1(1), 41 - 58.

vii. Sasikumar, A. \& Kumar, K. (2013). Value Stream Mapping in a Manufacturing Company. International Journal of Commerce, Business and Management, 2(2), 1 - 11.

viii. Singh, M., Singh, G. \&Garg, J. (2015). Value Stream Mapping: A Case Study of Fastener Industry. IOSR Journal of Mechanical and Civil Engineering, 12(5), 7 - 10.

ix. Wofuru-Nyenke, O.K., Nkoi, B. \&Oparadike, F.E. (2019). Waste and Cost Reduction for a Water Bottling Process Using Lean Six Sigma. European Journal of Engineering and Technology Research, 4(12), 71 - 77.

x. Yuvamitra, K., Lee, J. \& Dong, K. (2017). Value Stream Mapping of Rope Manufacturing: A Case Study. International Journal of Manufacturing Engineering, 2017, 1 - 11.

xi. Zahraee, S.M., Hashemi, A., Abdi, A.A., Shahpanah, A. \&Rohani, J.M. (2014). Lean Manufacturing Implementation through Value Stream Mapping: A Case Study. Jurnal Teknologi, 68(3), 119 - 124.

xii. Zakuan, N. \&Saman, M.Z.M. (2009). Lean Manufacturing Concept: The Main Factor in Improving Manufacturing Performance - A Case Study. International Journal of Manufacturing Technology and Management, 17(4), 353 363. 